\title{
HUBUNGAN PAJANAN KEBISINGAN DENGAN GANGGUAN NON - AUDITORY PADA PEKERJA DI PT X BEKASI TAHUN 2019
}

\author{
Dena Meilinda Sumadika $^{1)}$, Andi Asnifatima ${ }^{2)}$, dan Anissatul Fathimah ${ }^{3)}$
}

\footnotetext{
${ }^{1)}$ Kesehatan Keselamatan Kerja, Program Studi Kesehatan, Fakultas Ilmu Kesehatan Universitas Ibn Khaldun Bogor Email: denameilindas@gmail.com

${ }^{2)}$ Program Studi Kesehatan Masyarakat, Fakultas Ilmu Kesehatan Universitas Ibn Khaldun Bogor Email: andiasnifatimah@gmail.com

${ }^{3)}$ Program Studi Kesehatan Masyarakat, Fakultas Ilmu Kesehatan Universitas Ibn Khaldun Bogor

Email: anissatul_fathimah@yahoo.com
}

\begin{abstract}
Abstrak
Kebisingan di tempat kerja seringkali menjadi masalah bagi tenaga kerja. Kebisingan merupakan potensi bahaya (hazard) fisik yang umumnya di jumpai di hampir seluruh kegiatan industrialisasi. Efek kebisingan dengan intensitas tinggi dan bahkan melebihi Nilai Ambang Batas (NAB) yang diterima oleh tenaga kerja dapat menimbulkan berbagai masalah kesehatan, diantaranya gangguan auditory dan gangguan non auditory di PT X Bekasi. Tujuan penelitian ini untuk mengetahui hubungan kebisingan serta karakteristik individu (umur, masa kerja, lama pajanan dan alat pelindung telinga) dengan gangguan non auditory effect pada pekerja PT.X Bekasi. Metode penelitian ini adalah penelitian kuantitatif dengan desain penelitian menggunakan cross sectional. Teknik pengambilan sampel menggunakan sampling jenuh dengan jumlah sampel penelitian sebesar 45 responden. Hasil analisis menunjukkan tidak ada hubungan antara kebisingan dengan keluhan non auditory ( $p$-value $=0.759)$, umur ( $p$-value $=0.384)$, masa kerja ( $p$-value=0.178), lama pajanan ( $p$-value $=1.000)$, terhadap gangguan non-auditory dimana $\alpha<0,05$. Area kerja yang memiliki kebisingan yang tinggi dan tidak memakai alat pelindung telinga saat di area bising dapat menimbulkan peluang gejala gangguan non-audiotory pada pekerja diharapkan perusahaan semakin mengutamakan keselamatan dan kesehatan tenaga kerja dengan lebih meningkatkan upaya pengendalian kebisingan yang sudah dilakukan dan menambah upaya lainnya yang dapat diterapkan di area kerja bising.
\end{abstract}

\section{Kata Kunci: Kebisingan, Gangguan Non-Audiotory}

\section{Pendahuluan}

Sektor industri merupakan sektor yang menyerap tenaga kerja terbanyak dibanding sektor lain. Oleh karena itu, perlindungan terhadap pekerja perlu diperhatikan. perlindungan tenaga kerja meliputi banyak aspek seperti keselatan, kesehatan, pemeliharaan moral kerja serta perlakuan yang sesuai dengan martabat manusia dan moral agama. Perlindungan tersebut bermaksud agar tenaga kerja secara aman melakukan pekerjaannya sehari-hari untuk meningkatkan produksi dan produktivitas nasional. Tenaga kerja harus memperoleh perlindungan dari berbagai aspek yang dapat menimpa dirinya dan mengganggu pekerjaannya (Suma'mur, 1993).

Terdapat sekitar 16 juta orang bekerja di sector manufaktur atau sekitar $13 \%$ dari total 
tenaga kerja di Amerika Serikat. Menurut Biro Statistik Tenaga Kerja, gangguan pendengaran akibat kerja adalah yang paling banyak tercatat sebagai penyakit akibat kerja di sector manufaktur (17.700 kasus dari 59.100 kasus) atau sekitar 1 dari 9 penyakit tercatat adalah gangguan pendengaran akibat kerja. Lebih dari $72 \%$ terjadi pada pekerja di sektor manufaktur (NIOSH, 2010).

Pajanan bising dapat menyebabkan dua jenis gangguan kesehatan. gangguan tersebut adalah gangguan non-audiotory dan gangguan audiotory. gangguan non-audiotory yaitu stress, berhubungan dengan fisologikal dan efek terhadap sikap seseorang dan keperdulian mengenai keselamatan. gangguan audiotory yaitu kerusakan pada organ pendengaran yang disebabkan oleh pajanan kebisingan yang tinggi (CCOHS, 2015).

Menurut WHO (2001), gangguan kesehatan utama dari kebisingan adalah kerusakan pada organ pendengaran yang menyebabkan gangguan pendengaran. Hal ini sering disebabkan oleh suara di tempat kerja yang keras atau dengan suara musik yang keras, serta suara kembang api yang keras, selain efek kebisingan audiotory ini,perhatian juga harus diberikan untuk gangguan nonauditory. gangguan non-audiotory terjadi pada level yang lebih rendah dari yang dibutuhkan untuk merusak organ pendengaran.

\section{Metode Penelitian}

Jenis penelitian yang akan digunakan adalah jenis penelitian kuantitatif Penelitian ini menggunakan metode pendekatan cross sectional.

Populasi pada penelitian ini adalah seluruh pekerja PT.X Bekasi yang berjumlah 45 Orang. Sampel yang diambil yaitu pekerja yang dapat mewakili populasi pengambilan sampel dilakukan dengan menggunakan sampling jenuh. Sampling jenuh adalah
Industri Ready Mixed Concrete merupakan industri yang bergerak sebagai pemasok beton siap pakai. Beton merupakan bahan bangunan dasar yang digunakan dalam pembangunan komersial dan bangunan industri, jembatan. jalan raya, trotoar, rumah, waduk dan struktur lainnya.bahan ini fleksibel dan mudah diterapkan namun kuat dan tahan lama, terbuat dari campuran semen, air dan agregat. Meskipun beton dapat di produksi di tempat di mana ia akan digunakan, industri kontruksi bergantung pada beton jadi, yang diproduksi di fasilitas terdekat dan dikirimkan ke lokasi dengan truk (Clark, 2001).

PT. X adalah perusahaan pemasok beton siap pakai (Readymix Concrete), sama seperti perusahaan Readymix Concrete lainya , PT. X juga tidak lepas dari hazard saat melakukan proses produksi, salah satunya kebisingan. Berdasarkan hasil observasi awal yang dilakukan di PT. X Plant Jatiwarna Bekasi pada bagian produksi terdapat mesinmesin yang menimbulkan kebisingan, seperti Mesin Garding dan Fan Mixer selain itu sumber kebisingan lainnya juga ada pada truk mixer, loader, conveyor, pompa, compresor dan sebagainya. Dimana pekerja bekerja selama 8 jam per hari (dengan waktu istirahat 1 jam). Oleh karena itu, penulis ingin mengkaji Hubungan antara Pajanan kebisingan dengan gangguan Non-Audiotory pada pekerja di PT. X Bekasi.

tekhnik penentuan sampel bila semua anggota populasi digunakan sebagai sampel. Dimana Hal ini dilakukan karena jumlah populasi nya yang berjumlah 45 orang.

Data primer yang digunakan dalam penelitian ini antara lain pengukuran kebisingan area sekitar truk mixer dengan sound level meter, pengisian kuesioner terkait informasi mengenai umur, pekerja,masa kerja dan gangguan non-audiotory, serta 
wawancara terkait penggunaan alat pelindung telinga. Data sekunder yang akan diteliti dapat diperoleh dari profil perusahaan, jumlah dan daftar nama pekerja, alur produksi, informasi yang berkaitan dengan kebisingan dan non auditory dari berbagai media seperti internet, buku, jurnal, dan lain sebagainya.

Instrumen yang digunakan dalam penelitian ini adalah dengan menggunakan kuesioner yang didalamnya berisi variablevariabel yang telah ditentukan sebelumnya. Variabel yang diteliti dalam penelitian ini adalah kebisingan, umur, masa kerja, lama pajanan. Dimana nanti akan diketahui bagaimana hubungan dari variabel tersebut dengan gangguan non-audiotory (fisiologis, psikologis, dan komunikasi) dan mengetahui gambaran alat pelindung telinga pada pekerja di PT X Bekasi tahun 2019.

Pengolahan data ini dilakukan dengan pengkodean data, pengeditan data, memasukan data dan pempersihan data. Analisis bivariat dilakukan setelah analisis univariat, analisis bivariat dilakukan untuk mengetahui hubungan varibel bebas dengan variabel terikat dengan menggunakan uji statistik chi square.

\section{Hasil dan Pembahasan}

\section{1) Hubungan Kebisingan Dengan Gangguan Non-Audiotory pada pekerja di PT X Bekasi tahun 2019.}

Dalam penelitian ini dapat diketahui bahwa sebanyak 11 responden (61.1\%) yang terpapar kebisingan $<85 \mathrm{dBA}$ mengalami gangguan non-audiotory dan 7 responden (38.8\%) yang tidak mengalami gangguan non-audiotory Sebanyak 14 responden (51.8\%) yang terpapar kebisingan $>=85 \mathrm{dBA}$ mengalami gangguan non-audiotory dan 13 responden $(48.1 \%)$ yang tidak mengalami gangguan non-audiotory

Tabel 1 Hubungan antara Kebisingan dengan Gangguan Non-audiotory Pada Pekerja di PT X Bekasi Tahun 2019

\begin{tabular}{|c|c|c|c|c|c|c|c|c|c|}
\hline \multirow{3}{*}{$\begin{array}{l}\text { Intensitas } \\
\text { Kebisingan }\end{array}$} & \multicolumn{4}{|c|}{ Non Auditory Effect } & & & \multirow{3}{*}{$P$ Value } & \multirow{3}{*}{ OR } & \multirow{3}{*}{$(95 \%$ CI) } \\
\hline & \multicolumn{2}{|c|}{$\begin{array}{l}\text { Tidak Ada } \\
\text { Gangguan }\end{array}$} & \multicolumn{2}{|c|}{$\begin{array}{c}\text { Ada } \\
\text { Gangguan }\end{array}$} & \multicolumn{2}{|c|}{ Total } & & & \\
\hline & $\mathbf{N}$ & $\%$ & $\mathbf{N}$ & $\%$ & $\mathbf{N}$ & $\%$ & & & \\
\hline$<85 \mathrm{Dba}$ & 7 & 38.8 & 11 & 61.1 & 18 & 100 & \multirow{3}{*}{0.759} & \multirow{3}{*}{0.685} & \multirow{3}{*}{$\begin{array}{l}(0.204- \\
2.302)\end{array}$} \\
\hline$>=85 \mathrm{dBA}$ & 13 & 48.1 & 14 & 51.8 & 27 & 100 & & & \\
\hline Jumlah & 20 & 44.4 & 25 & 55.5 & 45 & 100 & & & \\
\hline
\end{tabular}

Sumber: Data Primer

Berdasarkan hasil penelitian bahwa, tidak ada hubungan yang bermakna antara kebisingan dengan non-audiotory.diperoleh nilai p-value sebesar 0.759 (p-value > 0.05) yang artinya secara perhitungan statistik Indikator tidak adanya hubungan antara kedua variabel tersebut adalah nilai P-value $>(0,05)$. Diketahui nilai $\mathrm{OR}=0.685$ dengan $95 \% \mathrm{CI}=$ (0.204-2.302) yang artinya pekerja yang terpapar kebisingan $>=85 \mathrm{dBA}$ mempunyai risiko 0.685 kali memiliki gangguan nonaudiotory dibandingkan dengan pekerja yang terpapar kebisingan $<85 \mathrm{dBA}$.

Pengukuran pajanan kebisingan dilakukan hanya dalam satu waktu, jadi belum bisa menggambarkan pajanan kebisingan selama satu shift penuh (24 jam) pengukuran hanya dilakukan pada pagi-siang hari. Tidak melakukan pengukuran dosis kebisingan personal yang diterima pekerja, sehingga 
belum bisa menghubungkan secara langsung antara intensitas kebisingan pada sumber bising dengan gangguan non-audiotory karena kondisi pekerja yang tidak menetap dalam tugasnya dan hasil pengukuran bersifat homogen.

Dalam penelitian Yustiawan (2015) Mengenai hubungan dosis pajanan kebisingan personal dengan gangguan non adiotory pada pengemudi truk mixer PT $X$ Jakarta menjelaskan bahwa tidak ada hubungan antara dosis pajanan kebisingan personal dengan gangguan non-audiotory tidak dapat di uji statistik dikarenakan data yang homogen pada dosis pajanan kebisingan.

Hal tersebut tidak sejalan dengan peneltian Tasya (2018) mengenai hubungan kebisingan dengan keluhan non-audiotory pada pada pekerja weaving PT. Unitex bahwa ada hubungan antara kebisingan dengan keluhan non-audiotory ( $\mathrm{p}$-value $=0,016$ ). penelitian yang dilakukan oleh Yulianto (2013) yang menyatakan bahwa terdapat hubungan antara intensitas kebisingan dengan gangguan non auditory yaitu gangguan komunikasi, gangguan fisiologi dan komunikasi.

\section{2) Hubungan Umur Dengan Gangguan Non-Audiotory pada pekerja di PT X Bekasi tahun}

2019.

Dalam penelitian ini dapat diketahui bahwa, sebanyak 29 responden berusia(>= 30 tahun), dimana sebanyak 18 responden $(62.0 \%)$ mengalami gangguan non-audiotory dan 11 responden (37.9 \%) tidak mengalami gangguan non-audiotory. Dan sebanyak 16 responden berusia ( $<30$ tahun), dimana sebanyak 7 responden $(43.7 \%)$ mengalami gangguan non-Tidak ada gangguannonaudiotory. audiotory dan 9 responden $(56.3 \%)$

Tabel 2 Hubungan Antara Umur Dengan Gangguan Non-Audiotory Pada Pekerja Di PT X Bekasi Tahun 2019

\begin{tabular}{|c|c|c|c|c|c|c|c|c|c|}
\hline \multirow{3}{*}{ Umur } & \multicolumn{4}{|c|}{ Non Auditory Effect } & & & \multirow{3}{*}{$\begin{array}{c}P \\
\text { Value }\end{array}$} & \multirow{3}{*}{ OR } & \multirow{3}{*}{$\begin{array}{c}(95 \% \\
\text { CI })\end{array}$} \\
\hline & \multicolumn{2}{|c|}{$\begin{array}{l}\text { Tidak Ada } \\
\text { Gangguan }\end{array}$} & \multicolumn{2}{|c|}{$\begin{array}{c}\text { Ada } \\
\text { Gangguan }\end{array}$} & \multicolumn{2}{|c|}{ Total } & & & \\
\hline & $\mathbf{N}$ & $\%$ & $\mathbf{N}$ & $\%$ & $\mathbf{N}$ & $\%$ & & & \\
\hline $\begin{array}{l}<30 \\
\text { tahun }\end{array}$ & 9 & 56.3 & 7 & 43.7 & 16 & 100 & & & \\
\hline $\begin{array}{l}>=30 \\
\text { tahun }\end{array}$ & 11 & 37.9 & 18 & 62.0 & 29 & 100 & 0.384 & 2.104 & $\begin{array}{c}(0.609- \\
7.272\end{array}$ \\
\hline Jumlah & 20 & 44.4 & 25 & 55.6 & 45 & 100 & & & \\
\hline
\end{tabular}

Berdasarkan hasil penelitian bahwa, tidak ada hubungan yang bermakna antara umur dengan non-audiotory diperoleh $p$-value sebesar 0.384. oleh karena nilai p-value > (0.05), artinya secara perhitungan statistik tidak ada hubungan yang bermakna antara umur dengan gangguan Non-audiotory. Dari uji statistik ini juga diketahui nilai $\mathrm{OR}=2.104$ dengan $95 \% \mathrm{CI}=(0.609-7.272)$ yang artinya pekerja yang berumur 30 tahun keatas mempunyai risiko 2.104 kali memiliki gejala gangguan non-audiotory dibandingkan dengan pekerja yang berumur dibawah 30 tahun.

Responden yang menjadi obyek penelitian mayoritas berumur diatas 30 tahun, sehingga variabel usia kurang dapat dijelaskan melalui uji bivariat karena tidak 
dapat menguatkan teori mengenai hubungan usia yang dapat mempengaruhi keluhan non auditory effect pada pekerja. Usia pada dasarnya merupakan faktor yang berkontribusi memunculkan keluhan non auditory. Usia termasuk unsur intrinsik yang berasal dari dalam tubuh pekerja. Faktor usia mampu memunculkan keluhan non auditory effect terkait dengan fungsi fisiologis tubuh pekerja. Seharusnya, jika faktor usia bersinergi dengan intensitas kebisingan tinggi, maka kemungkinan munculnya keluhan non auditory effect semakin besar. Ketiadaan hubungan antar variable tersebut kemunginan disebabkan persebaran data usia yang kurang merata. Usia tenaga kerja di PT.X Bekasi tersebar pada rentang 23-45 tahun saja, dengan usia termuda 23 tahun dan tertua 45 tahun. Menurut peneliti, penyebab hasil uji statistik tidak menunjukkan hubungan signifikan adalah penentuan titik potong yang kurang tepat, karena titik potong dapat mempengaruhi hasil uji statistik.

Hasil tersebut sejalan dengan hasil penelitian Tasya (2018) mengenai hubungan kebisingan dengan keluhan non-audiotory pada pada pekerja weaving PT. Unitex bahwa tidak ada hubungan yang bermakna antara umur dengan keluhan non auditory effect ( $p$ value $=0,522$ ). Dalam penelitian yustiawan (2015) mengenai hubungan antara dosis pajanan kebisingan personal dengan gangguan non-audiotory pada pengemudi truk mixer PT X Jakarta yang menyatakan bahwa tidak ada hubungan antara umur dengan gangguan non-audiotory akibat bising. Hasil penelitian Agustin (2015) menyatakan tidak ada hubungan umur dengan keluhan non auditory di area turbin dan boiler ( $p$-value $=$ $0,655)$.

\section{3) Hubungan Masa Kerja Dengan Gangguan Non-Audiotory pada pekerja di PT X Bekasi tahun 2019. \\ Dalam penelitian ini dapat diketahui bahwa, sebanyak 4 responden yang bekerja diatas 5 tahun dimana sebanyak 4 responden (100\%) mengalami gangguan non-auditory. Dan \\ 5 tahun dimana 21 responden (51.3\%) mengalami gangguan non-auditory dan sebanyak 20 responden(48.7\%) tidak ada gangguan non-auditory.}

sebanyak 41 responden yang bekerja dibawah

Tabel 3 Hubungan Antara Masa Kerja Dengan Gangguan Non- Audiotory Pada Pekerja Di PT X Bekasi Tahun2019

\begin{tabular}{|c|c|c|c|c|c|c|c|c|c|}
\hline \multirow{3}{*}{$\begin{array}{l}\text { Masa } \\
\text { Kerja }\end{array}$} & \multicolumn{4}{|c|}{ Non Auditory Effect } & & & \multirow{3}{*}{$\begin{array}{c}P \\
\text { Value }\end{array}$} & \multirow{3}{*}{ OR } & \multirow{3}{*}{$(95 \%$ CI $)$} \\
\hline & \multicolumn{2}{|c|}{$\begin{array}{l}\text { Tidak Ada } \\
\text { Gangguan }\end{array}$} & \multicolumn{2}{|c|}{$\begin{array}{c}\text { Ada } \\
\text { Gangguan }\end{array}$} & \multicolumn{2}{|c|}{ Total } & & & \\
\hline & $\mathbf{N}$ & $\%$ & $\mathbf{N}$ & $\%$ & $\mathbf{N}$ & $\%$ & & & \\
\hline$<5$ Tahun & 20 & 48.7 & 21 & 51.3 & 41 & 100 & \multirow{3}{*}{0.178} & \multirow{3}{*}{0.512} & \multirow{3}{*}{$\begin{array}{c}(0.380- \\
0.691)\end{array}$} \\
\hline$>=5$ tahun & 0 & 0 & 4 & 100 & 4 & 100 & & & \\
\hline Jumlah & 20 & 44.4 & 25 & 55.5 & 45 & 100 & & & \\
\hline
\end{tabular}

Sumber: Data Primer Penelitian

Berdasarkan hasil penelitian bahwa, tidak ada hubungan yang bermakna antara masa kerja dengan non-audiotory diperoleh nilai $p$-value sebesar 0178 . oleh karena nilai p-value > (0.05), maka dapat disimpulkan bahwa tidak ada hubungan yang bermakna antara masa kerja dengan gangguan nonaudiotory. diketahui nilai $\mathrm{OR}=0.512$ dengan 
95\% $\mathrm{CI}=(0.380-0.691)$ yang artinya pekerja yang bekerja 5 tahun ke atas mempunyai risiko 0.512 kali memiliki gangguan non audiotory dibandingkan dengan pekerja yang bekerja dibawah 5 tahun.

Responden yang menjadi obyek penelitian mayoritas berumur bekerja diatas 5 tahun, sehingga variabel masa kerja kurang dapat dijelaskan melalui uji bivariat karena tidak dapat menguatkan teori mengenai hubungan masa kerja yang dapat mempengaruhi keluhan non auditory effect pada pekerja.

Hasil penelitian ini juga didukung oleh penelitian Susanti (2010) yang menyatakan masa kerja yang lama lebih beresiko untuk mengalami keluhan non auditory berupa gangguan komunikasi, psikologis dan fisiologis. Hasil tersebut tidak sejalan dengan peneltian Yulianto (2013) mengenai faktorfaktor yang berhubungan dengan gangguan non-audiotory akibat kebisingan pada musisi rock yang menyatakan bahwa terdapat hubungan bermakna antara masa kerja dengan gangguan non-audotory.. Menurut Olishfski dalam Yulianto (2013) menyatakan bahwa durasi terpajan bising termasuk lamanya masa kerja merupakan faktor penyebab timbulnya keluhan subyektif pada pekerja.semakin lama masa kerja, semakin besar kerusakan yang terjadi pada fungsi pendengaran maupunnonpendengaran.

\section{4) Hubungan Lama Pajanan Dengan Gangguan Non-Audiotory pada pekerja di PT X Bekasi tahun 2019.}

Dalam penelitian ini dapat diketahui bahwa, sebanyak 39 responden yang bekerja diatas 8 jam kerja, dimana sebanyak 22 responden (56.5\%) mengalami gangguan non-auditory dan 17 responden (43.5\%) tidak ada gangguannon-auditory.Dan sebanyak 6

responden yang bekerja dibawah 8 jam dimana 3 responden(50.0 \%) mengalami gangguan non-auditory dan sebanyak 3 responden(50.0\%) tidak ada gangguan nonauditory.

Tabel 4 Hubungan Antara Lama Pajanan Dengan Gangguan Non-Audiotory Pada Pekerja Di PT X Bekasi Tahun 2019

\begin{tabular}{|c|c|c|c|c|c|c|c|c|c|}
\hline \multirow{3}{*}{$\begin{array}{c}\text { Lama } \\
\text { Pajanan }\end{array}$} & \multicolumn{4}{|c|}{ Gangguan Fisiologis } & & & \multirow{3}{*}{$\begin{array}{c}P \\
\text { Value }\end{array}$} & \multirow{3}{*}{ OR } & \multirow{3}{*}{$(95 \% \mathrm{CI})$} \\
\hline & \multicolumn{2}{|c|}{$\begin{array}{l}\text { Tidak ada } \\
\text { Gangguan }\end{array}$} & \multicolumn{2}{|c|}{$\begin{array}{c}\text { Ada } \\
\text { Gangguan }\end{array}$} & \multicolumn{2}{|c|}{ Total } & & & \\
\hline & $\mathbf{N}$ & $\%$ & $\mathbf{N}$ & $\%$ & $\mathbf{N}$ & $\%$ & & & \\
\hline$<8 \mathrm{Jam}$ & 3 & 50.0 & 3 & 50.0 & 6 & 100 & \multirow{3}{*}{1.000} & \multirow{3}{*}{1.294} & \multirow{3}{*}{$\begin{array}{c}(0,232- \\
7.234\end{array}$} \\
\hline$>=8 \mathrm{Jam}$ & 17 & 43.6 & 22 & 56.4 & 39 & 100 & & & \\
\hline Jumlah & 20 & 44.4 & 25 & 55.6 & 45 & 100 & & & \\
\hline
\end{tabular}

Berdasarkan hasil penelitian bahwa, tidak ada hubungan yang bermakna antara masa kerja dengan non-audiotory Dari hasil uji statistik diperoleh nilai $p$-value sebesar 1.000. oleh karena nilai $p$-value $>(0.05)$, maka dapat disimpulkan bahwa tidak ada hubungan yang bermakna antara lama pajanan dengan gangguan non-audiotory. diketahui nilai $\mathrm{OR}=1.294$ dengan $95 \% \mathrm{CI}=(0.232-$ 7.234) yang artinya pekerja yang bekerja 8 jam ke atas mempunyai risiko 1.294 kali memiliki gangguan non audiotory dibandingkan dengan pekerja yang bekerja dibawah 8 jam kerja.

Ketiadaan hubungan tersebut kemungkinan disebabkan adanya pengaruh 
faktor lain seperti lama pajanan yang berbedabeda. Pekerja menyatakan kondisi mereka yang telah terbiasa dengan keadaan lingkungan kerja yang bising. Selain itu, tidak adanya hubungan lama pajanan dengan keluhan pada tenaga kerja bisa disebabkan oleh beberapa faktor diantaranya tenaga kerja yang terpapar intensitas bising yang cukup tinggi namun waktu pajanannya tidak kontinyu sehingga memungkinkan seorang tenaga kerja mengalami pemulihan bising setelah berada ditempat kerja bising. Faktor kesadaran menggunakan APT yang kurang dalam melakukan pekerjaan di area bising sehingga risiko memiliki keluhan non auditory seperti gangguan komunikasi, gangguan psikologi dan fisiologis tetap ada.

Untuk mengetahui tingkat bahaya suatu kebisingan selain memperhatikan faktor intensitas kebisingan, indikator lain yang juga

\section{Gambaran Alat pelindung Telinga}

Penggunaan Alat Pelindung Telinga dikelompokan menjadi empat kategori yaitu tidak nyaman,mengganggu, lupa, dan tidak merasa perlu karena tidak terlalu berisik. Kategori tersebut dilihat dari alasan pekerja tidak memakai alat pelindung telinga. Sebanyak 14 (31.1\%) responden merasa tidak nyaman memakai alat pelindung telinga, 13 berperan penting terhadap penentuan bahaya kebisingan adalah durasi pajanan bising. Time-weighted Average (TWA) dalam hal ini digunakan pada waktu kerja 8 jam. Dasar pertimbangan dari TWA ini untuk menilai efek kebisingan yang diterima sebanding dengan lama pekerja terpajan bising (Work n.d.2008).

Hal ini sama dengan hasil penelitian Agustin (2015) menyatakan tidak ada hubungan lama pajanan dengan keluhan non auditory di area turbin dan boiler ( $p$-value = 0,535). Sriwahyudi (2014) juga menyatakan bahwa tidak ada hubungan lama pajanan dengan keluhan non auditory pada pekerja instalasi laundry. Hasil penelitian Sudirman (2014) p-value adalah 0,141 berarti tidak ada hubungan antara lama kerja dengan keluhan kesehatan non pendengaran.

responden (28.9\%) merasa mengganggu pekerjaan saat memakai alat pelindung telinga, 5 responden $(5.7 \%)$ lupa membawa alat pelindung telinga ketika sedang bekerja, dan 13 responden $(33.3 \%)$ tidak merasa perlu memakai alat pelindung telinga karena area kerja tidak terlalu berisik

Tabel 5 Distribusi Frekuensi Alat Pelindung Telinga Pada Pekerja di PT X Bekasi Tahun 2019

\begin{tabular}{|c|c|c|c|c|c|c|}
\hline Alasan responden & Frekuensi & $\begin{array}{c}\text { Presentase } \\
(\%)\end{array}$ & Mean & SD & $\begin{array}{c}\text { Max- } \\
\text { Min }\end{array}$ & $\begin{array}{r}\mathbf{9 5 \%} \\
\text { CI) }\end{array}$ \\
\hline Tidak Nyaman \\
$\begin{array}{c}\text { Mengganggu } \\
\text { Lupa }\end{array}$ & 14 & 31.1 & & & & \\
$\begin{array}{c}\text { Tidak merasa perlu } \\
\text { karena tidak terlalu } \\
\text { berisik }\end{array}$ & 5 & 6.7 & & & & \\
\hline Total & 13 & 28.9 & 2.42 & 1.252 & $5-14$ & $\begin{array}{r}2.05- \\
2.80\end{array}$ \\
\hline
\end{tabular}


Penggunaan Alat Pelindung Telinga (APT) dapat ditentukan oleh persediaan APT, kesadaran pekerja, pengawasan dari pihak manajemen SMK3 itu sendiri.di area kerja PT $\mathrm{X}$ disediakan Alat Pelindung Telinga untuk pekerja. Hasil penelitian Astuti (2013) mengenai hubungan intensitas kebisingan terhadap efek kesehatan non-audiotory bagian produksi PT Thokai menunjukan bahwa

\section{Kesimpulan dan Saran}

\section{Kesimpulan}

1. Hasil analisis antara Pajanan kebisingan dengan gangguan non-audiotory baik pada gejalafisiologis, psikologis dan komunikasi,secara statistik tidak ditemukan hubungan bermakna antara pajanan kebisingan dengan gangguan non-audiotory dengan nilai ( $p$-value $0.759>0.05$ ).

2. Hasil analisis antara umur dengan gangguan non-audiotory baik pada gejala fisiologis, psikologis dan komunikasi, secara statistik tidak ditemukan hubungan bermakna antara umur dengan gangguan non-audiotory dengan nilai ( $p$-value $0.384>0.05$.

3. Hasil analisis antara masa kerja dengan gangguan non-audiotory baik pada gejala fisiologis, psikologis dan komunikasi, secara statistik tidak ditemukan hubungan bermakna antara masa kerja dengan gangguan nonaudiotory dengan nilai ( $p$-value $0.178>0.05$ ).

4. Hasil analisis antara lama pajananan dengan gangguan non-audiotory baik pada gejala fisiologis, psikologis dan komunikasi, secara statistik tidak ditemukan hubungan bermakna antara lama pajanan dengan gangguan nonaudiotory dengan nilai (p-value 1.000 $>0.05$ ). pekerjaan yang tidak menggunakan alat pelindung telinga memiliki risiko mengalami gangguan psikologis 4 kali lebih besar dari pada pekerja yang menggunakan Alat Pelindung Telinga. Tetapi, hasil survey lainnya menunjukan bahwa tidak terdapat hubungan antara penggunaan Alat Pelindung Telinga dengan gangguan fisiologis dan gangguan komunikasi.

5. Gambaran Penggunaan Alat Pelindung Telinga dikelompokan menjadi empat kategori yaitu tidak nyaman,mengganggu, lupa, dan tidak merasa perlu karena tidak terlalu berisik. Kategori tersebut dilihat dari alasan pekerja tidak memakai alat pelindung telinga. Sebanyak 14 (31.1\%) responden merasa tidak nyaman memakai alat pelindung telinga, 13 responden $(28.9 \%)$ merasa mengganggu pekerjaan saat memakai alat pelindung telinga, 5 responden (5.7\%) lupa membawa alat pelindung telinga ketika sedang bekerja, dan 13 responden $(33.3 \%)$ tidak merasa perlu memakai alat pelindung telinga karena area kerja tidak terlalu berisik.

\section{Saran}

1. Melakukan pengukuran kebisingan pada area yang berpotensi menimbulkan kebisingan tinggi atau pada pekerja yang berpotensi terpajan kebisingan tinggi

2. Memberikan pelatihan dan menyediakan alat pelindung telinga berupa earplug/earmuff serta informasi mengenai efek buruk dari kebisingan kepada pekerja.

3. Melakukan pengukuran audiometri secara rutin sebaiknya dilaksanakan oleh perusahaan minimal pada pekerja 
yang berpotensi terpajan kebisingan dan baiknya seluruh pekerjaagan bisa

\section{Daftar Pustaka}

[1]. Adha, Maghfira. 2018. Hubungan Kebisingan Di Bandara Halim Perdanakusuma Jakarta Timur Terhadap Gangguan Non- Auditori Permukiman Penduduk Wilayah Buffer. Jurnal. Fakultas Kesehatan Masyarakat. Semarang: Universitas Diponegoro.

[2]. Agustin, Ike (2015). Hubungan antara intensitas kebisingan dengan keluhan non auditory effect di area turbin dan boiler pembangkit. Skripsi. Jember: Universitas Jember.

[3]. Arif, Maskur. (2012). Persepsi Masyarakat Mengenai Gangguan Non Auditory Terhadap Tingkat Kebisingan Di Kawasan Pemukiman Di Sekitar Bandar Internasional Soekarno-Hatta Pada Tahun 2012. Skrispi. Depok: Universitas Indonesia.

[4]. Arikunto, Suharsimi. (2013). Prosedur Penelitian. Jakarta: PT. Rineka Cipta.

[5]. Aquariza, Tasya (2018). Hubungan kebisingan dengan keluhan non auditory effect pada pekerja bagian weaving di PT. Unitex bogor tahun 2018.Skipsi. Bogor: Universitas Ibn Khaldun.

[6]. Bungin, Burhan.Metodologi Penelitian Kuantitatif Komunikasi, Ekonomi dan Kebijakan Publik Serta Ilmu-Ilmu Sosial Lainnya, 2010 Jakatra : Kencana

[7]. Cara mudah analisis data univariat \& crosstabs (tabel silang) dengan SPSS diakses

https://www.youtube.com/watch? $v=X k 4$ P7YiNr-8 pada tanggal 11Juli 2019.

[8]. CCOHS (2015) NOISE-Audiotory effects diakses di https://www.tequipment.net/BK735.html pada tanggal 20 Januari 2019. diketahui kondisi pendengaran dari setiap pekerja.

[9]. Damajanty, 2015. Pengaruh Pajanan Bising Terhadap Pendengaran Dan Tekanan Darah Pada Pekerja Game Center Di Kota Manado.Jurnal. Fakultas Kesehatan Masyarakat Universitas Sam Ratulangi.Manado: Universitas Sam Ratulangi.

[10]. Harrianto, Ridwan. (2010). Buku Ajar Kesehatan Kerja. Jakarta: EGC

[11]. Iwan, Ramdan. 2014. Hubungan Paparan Kebisingan Dengan Gangguan Psikologis, Gangguan Komunikasi Dan Tekanan Darah Pada Tenaga Kerja Pltd Kasamarinda. Jurnal. fakultas Kesehatan Masyarakat Universitas Mulawarman. Samarinda : Universitas Mulawarman

[12]. Keputusan Menteri Negara Lingkungan Hidup No. KEP 48/MENLH/11/1996. BAKU TINGKAT KEBISINGAN.

[13]. Khairul, Yustriawan. 2015. Hubungan dosis pajanan kebisingan personal dengan gangguan non-audiotory pada pengemudi truk mixer di PT Ramli, Soehatman. 2010. Sistem Manajemen Keselamatan dan Kesehatan Kerja. Jakarta: Dian Rakyat

[14]. Prasetya, E. (2018). Pemberdayaan Masyarakat Tentang Kesehatan, Pendidikan dan Kreatifitas. Abdi Dosen: Jurnal Pengabdian Pada Masyarakat 2 (1), 19-25.

[15]. Rizky, Ardian.2013. Faktor-Faktor Yang Berhubungan Dengan Gangguan Nonauditory Akibat Kebisingan Pada Musisi Rock. Jurnal. Fakultas Kesehatan Masyarakat. Semarang: Universitas Diponegoro. 
[16]. Sasongko, D.P, dkk. 2000. Bising Lingkungan. Semarang: Badan Penerbit Universitas Diponegoro. 